\title{
Modeling a proton exchange membrane (PEM) fuel cell system as a hybrid power supply for standalone applications.
}

\author{
ALI, D. and AKLIL-D'HALLUIN, D.D.
}




\section{Modeling a Proton Exchange Membrane (PEM) Fuel Cell System as a hybrid power supply for standalone applications}

\author{
Dr. Dallia Ali/ Researcher \\ School of Engineering \\ The Robert Gordon University \\ Schoolhill, Aberdeen, UK \\ d.ali@,rgu.ac.uk
}

\author{
Dr. Daniel D. Aklil-D’Halluin/Managing Director \\ Pure Energy Centre \\ Hagdale Industrial Estate, Baltasound \\ Unst, Shetland, ZE2 9DS, UK \\ daniel.pure@btconnect.com
}

\begin{abstract}
Fuel Cells (FC) can help in contributing to environmental pressures by maximizing the use of renewables in the energy production and using hydrogen produced with no $\mathrm{CO}_{2}$ emission from Renewable Energy Systems (RES). FCs also contributes to energy security concerns by allowing a wider choice of fuels and by using it in combined heat and power applications (CHP). Thus using fuel cells will help in complying with the Scottish Government requirements. However, wide use of fuel cells in power applications cannot be reached before developing a prototype model for the simulation and performance evaluation of the fuel cell generation system to ensure its optimum performance in both stand-alone and gridconnected environments.
\end{abstract}

Keywords- Hydrogen technology, Low Carbon, PEM Fuel cells, Mathematical modelling, Block Simulation

\section{INTRODUCTION}

A solar panel, a wind turbine or a micro-hydro generator can be used to drive an electrolyser to break water into hydrogen and oxygen gases, where hydrogen can be stored to be used in fuel cells and generate energy whenever needed. Fuel cells [1, 2, and 3] are electrochemical devices that convert the chemical energy of a gaseous fuel directly into electricity, heat and water thereby eliminating pollution. They combine the best features of engines (can operate for as long as fuel is available) and batteries (produce electricity directly from fuel without combustion reducing emissions and noise and increasing efficiency). They are able to provide power and heat at different scales in any location, and to operate on fuels ranging from fossil fuels through biomass based fuels to renewable. Polymer Electrolyte membrane fuel cell (PEMFC) emerges as one of the most promising for both stationary and automotive applications [4]. Different models for PEMFC are available in literature [4-10] but these are either more suitable for electrochemical purposes rather than electrical engineering [4-7], or presented in a very simplified electrical model [8-10] to be used in deriving a control system. Also most of the available models cannot be easily modified to allow investigation of alternative combinations of system design and operating parameters. In addition, in power generation systems, the dynamic response is extremely important for the planner especially when there is injection of energy into the grid. Hence, this paper presents a modular design prototype that is easy to modify to allow simulation of different configurations of a PEMFC, reducing the time and cost associated with a parameter investigation and enable investigation of transients. The model can be used as an initial step to prescribe internal design modifications and/or external controller designs to improve its transient behavior. The proposed model is implemented in MATLAB/SIMULINK $[11,12]$ and was verified by generating sample results for a Ballard NEXA ${ }^{\mathrm{TM}}$ Power module [13]. Results from the verification investigation were compared to benchmark/experimental data indicating that the developed prototype is accurate in simulating a PEMFC and predicting its performance. The proposed model was also compared to a simplified model [8], results generated for a Ballard V PEMFC [14] were compared showing that the proposed model is more accurate in simulating the fuel cell, especially at operating current densities higher than $1 \mathrm{~A} / \mathrm{cm}^{2}$ $\left(1000 \mathrm{~mA} / \mathrm{cm}^{2}\right)$.

\section{THE FUEL CELL SYSTEM}

A fuel cell stack is formed of a number of cells referred as MEA (Membrane-electrode assembly) composed of a membrane (electrolyte) sandwiched between two porous electrodes. The stack' voltage is determined by the number of cells, and current is determined by the active area of the cells. Other parts of a fuel cell system include: pumps and blowers, compressors, cooling system, a power conditioning (voltage regulator to make the cell $\mathrm{DC}$ output suitable for connection to an electrical load) and sometimes a DC/AC inverter. A fuel processing system is needed if the fuel cell does not use pure hydrogen. A controller is needed to coordinate the parts of the system. The fuel cell system consists in general of four sections as shown in Fig.1. To utilize this system a mathematical model, that simulates it, is necessary in order to analyze the system behavior in different operating conditions".

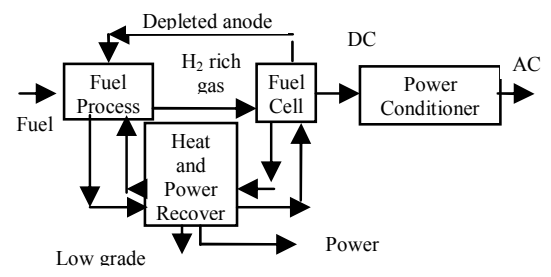

Fig. 1 Block Diagram of a Fuel cell Power Plant 


\section{PEMFC BASIC PRINCIPLES AND MODELLING}

A PEMFC depends primarily on a modified polymer membrane (Nafion: as it is mechanically strong, can absorb large quantities of water and is a good proton conductor), coated with highly dispersed catalyst particles (best is platinum although it is major factor in cost of PEMFC). The electrodes are usually flat and porous to allow the electrolyte from one side and the gas from the other side to penetrate it. It has a low operating temperature between 50 and $90{ }^{\circ} \mathrm{C}$.

The electrochemical equations are given by:

At Anode: $\quad \mathrm{H}_{2} \rightarrow 2 \mathrm{H}^{+}+2 \mathrm{e}^{-}$

At Cathode: $2 \mathrm{H}^{+}+2 \mathrm{e}^{-}+1 / 2 \mathrm{O}_{2} \rightarrow \mathrm{H}_{2} \mathrm{O}+$ heat

Overall reaction: $\mathrm{H}_{2}+1 / 2 \mathrm{O}_{2} \rightarrow \mathrm{H}_{2} \mathrm{O}+$ heat

Where: first equation determines amount of hydrogen needed to be fed to anode to meet a load, second equation determines amount of oxygen needed to cathode to maintain reaction, while the third equation determines water produced.

\section{Modeling of a PEMFC:}

\section{A. Anode and Cathode (Reactants) flow Models:}

In these models the dynamically varying pressure of the reactant gas flows (hydrogen and air) are calculated.

To calculate the $\mathrm{O}_{2}$ usage rate:

We know from the basic reaction of fuel cell that 4 electrons are transferred for each mole of oxygen,

$\therefore$ Charge $=4 \mathrm{~F} \times$ amount of oxygen

Where; F: Faraday's constant

$\therefore$ Oxygen usage (rate) $=\mathrm{I} / 4 \mathrm{~F}$ moles $/ \mathrm{s}$

Oxygen usage $=\mathrm{IN} / 4 \mathrm{~F}$ moles $/ \mathrm{s}$

Or, since $\mathrm{P}=\mathrm{V}_{\mathrm{FC}} \times \mathrm{I} \times \mathrm{N}$, then $\mathrm{I}=\mathrm{P} / \mathrm{N} \mathrm{v}_{\mathrm{FC}}$

Where; $\mathrm{N}$ : number of cells in a fuel cell stack

I: rate of flow of charge (current) in a single cell.

P: power of fuel cell stack.

$\mathrm{V}_{\mathrm{FC}}$ : voltage of each cell and $\mathrm{V}_{\mathrm{F} . \mathrm{C}}=\mathrm{Stack} \mathrm{o} / \mathrm{p}$ voltage

$\therefore$ Oxygen usage $=\mathrm{P} / 4 \mathrm{~F} \mathrm{~V}_{\mathrm{FC}}$ moles $/ \mathrm{s}$

Substituting with the molar mass of $\mathrm{O}_{2}$

$\therefore$ Oxygen usage $=8.29 \times 10^{-8} \times\left(\mathrm{P} / \mathrm{V}_{\mathrm{FC}}\right) \mathrm{Kg} / \mathrm{s}$

However the molar proportion of oxygen in air is 0.21 ;

$\therefore$ Air usage $=3.57 \times 10^{-7} \times\left(\mathrm{P} / \mathrm{V}_{\mathrm{FC}}\right) \mathrm{Kg} / \mathrm{s}$

To calculate the $\mathrm{H}_{2}$ usage rate:

Similarly, from the basic reaction of fuel cell 2 electrons are transferred for each mole of hydrogen, so:

Charge $=2 \mathrm{~F} \times$ amount of hydrogen

$\therefore$ Hydrogen usage $=\mathrm{I} / 2 \mathrm{~F}$ moles $/ \mathrm{s}$

Or, Hydrogen usage $=\mathrm{P} / 2 \mathrm{~F} \mathrm{~V}_{\mathrm{FC}}$ moles $/ \mathrm{s}$

The molar mass of $\mathrm{H}_{2}$ is $2.02 \times 10^{-3} \mathrm{~kg} / \mathrm{mol}$

$\therefore$ Hydrogen usage $=1.05 \times 10^{-8} \times\left(\mathrm{P} / \mathrm{V}_{\mathrm{FC}}\right) \mathrm{Kg} / \mathrm{s}$

The $\mathrm{H}_{2}$ usage rate is useful to know the electrical energy that could be produced from a given mass or volume of hydrogen [Specific enthalpy $(\mathrm{HHV})=39.7 \mathrm{kWh} / \mathrm{kg}$ ].

\section{B. Membrane Hydration Model:}

This represents the process of water transfer across the membrane. Dry membranes reduce proton conductivity and flooded ones block the pores in the electrodes leading to high voltage losses. Ideally, air (oxygen) blown over the cathode diffuse water from the cathode to the anode and throughout electrolyte and dry out any excess water providing a suitable state of hydration, but perturbations can happen. Thus an adjustable parameter $\psi$ [3] influenced by membrane preparation procedure and relative humidity; will be included in the proposed model.

$\psi=14$ under ideal condition of $100 \%$ relative humidity. $\psi=22$ or 23 under oversaturated conditions.

\section{Stack Voltage Model:}

The typical electrical characteristic of a fuel cell is normally given in the form of a polarization curve, which is a plot of the cell voltage versus cell current density (current/unit cell active area). The difference between actual voltage $V_{\text {F.C }} \&$ ideal voltage of a fuel cell $\mathrm{E}_{\mathrm{Nernst}}$ represents the losses in the cell. As more current is drawn the voltage decreases (due to the FC electrical resistance, inefficient reactant gas transport \& slow reaction). As low voltage indicates low efficiency of the $\mathrm{FC}$, then low load operation is preferred. Notice that since Gibbs free energy of formation changes with temperature \& state, thus the polarization curve varies with different operating conditions as different temperatures, reactant partial pressures and membrane humidity. Therefore, the voltage model should calculate the stack voltage as a function of stack current, reactant partial pressures, cell temperature, and membrane humidity using a combination of physical and empirical relationships. The $\mathrm{o} / \mathrm{p}$ voltage for a PEMFC is basically defined by [3]:

$\mathrm{V}_{\mathrm{F} . \mathrm{C}}=\mathrm{N}\left[\mathrm{E}_{\mathrm{Nernst}}-\mathrm{L}\right]$

Where: $\mathrm{E}_{\mathrm{Nernst}}=$ Cell potential obtained in an open-circuit thermodynamic balance (no load).

$\mathrm{L}=$ Voltage losses $=\Delta \mathrm{V}_{\text {activation }}+\Delta \mathrm{V}_{\text {ohmic }}+\Delta \mathrm{V}_{\text {conc }}$

$\Delta \mathrm{V}_{\text {activation }}$ : activation losses; $\Delta \mathrm{V}_{\text {ohmic }}$ : ohmic losses; and

$\Delta \mathrm{V}_{\text {conc }}$ : concentration losses.

- To find $\mathrm{E}_{\text {Nernst }}$ :

As it was shown before for each mole of hydrogen 2 electrons flow, thus the flowing charge is:

Charge $=-2 \mathrm{~F}$ coulombs

Electrical work done $=$ charge $\times$ voltage

$\therefore \Delta \mathrm{g}_{\mathrm{f}}=-2 \mathrm{FE}$ joules

$\therefore \mathrm{E}=-\Delta \mathrm{g}$ f $/ 2 \mathrm{~F}$

Where; E: maximum electromotive force or reversible produced open circuit voltage of fuel cell at standard temperature $25^{\circ} \mathrm{C}$.

$\Delta \mathrm{g}$ f: per mole change in Gibbs free energy of formation $(\mathrm{J} / \mathrm{mol})$, which is the available energy to do external work.

To obtain $E_{\text {Nernst }}[7]$ an extra term is added to take into account changes in temperature with respect to standard reference temperature $25^{\circ} \mathrm{C}$.

$\therefore \mathrm{E}_{\mathrm{Nernst}}=-\Delta \mathrm{g}_{\mathrm{f}} / 2 \mathrm{~F}+\Delta \mathrm{S} / 2 \mathrm{~F}\left(\mathrm{~T}-\mathrm{T}_{\mathrm{ref}}\right)$

Where, $\Delta \mathrm{g}_{\mathrm{f}}=\left(\mathrm{g}_{\mathrm{f}}\right)_{\mathrm{H} 2 \mathrm{O}}-\left(\mathrm{g}_{\mathrm{f}}\right)_{\mathrm{H} 2}-1 / 2\left(\mathrm{~g}_{\mathrm{f}}\right)_{\mathrm{O} 2}$

$\Delta \mathrm{S}$ : Change of the entropy $(\mathrm{J} / \mathrm{mol})$.

$\mathrm{T}$ : Fuel cell operation temperature in $\mathrm{K}$; and $\mathrm{T}_{\text {ref: }}$ the reference temperature.

As the Gibbs free energy changes with reactant pressure and concentration; Thus:

$\Delta \mathrm{g}_{\mathrm{f}}=\Delta \mathrm{g}_{\text {fo }}+\mathrm{RT} \ln \left[\mathrm{P}_{\mathrm{H} 2} \times\left(\mathrm{P}_{\mathrm{O} 2}\right)^{1 / 2}\right] / \mathrm{P}_{\mathrm{H} 2 \mathrm{O}}$

$\therefore \mathrm{E}=\mathrm{E}_{\mathrm{o}} / 2 \mathrm{~F}+\mathrm{RT} \ln \left[\mathrm{P}_{\mathrm{H} 2} \times\left(\mathrm{P}_{\mathrm{O} 2}\right)^{1 / 2}\right] / \mathrm{P}_{\mathrm{H} 2 \mathrm{O}}$ 
R: universal gas constant $=8.3145 \mathrm{~J} / \mathrm{K} . \mathrm{mol}$.

$\mathrm{P}_{\mathrm{H} 2}, \mathrm{P}_{\mathrm{O} 2}, \mathrm{P}_{\mathrm{H} 2 \mathrm{O}}$ : Partial pressures of hydrogen, oxygen and water atm.

From equations (3), (4) and by substituting with the known values of the constants and the reference temperature, we obtain the final equation:

$\mathrm{E}_{\mathrm{Nernst}}=1.229-0.85 \times 10^{-3} \times(\mathrm{T}-298.15)+4.3085 \times 10^{-5} \times \mathrm{T} \times$

$\left[\ln \left(\mathrm{P}_{\mathrm{H} 2}\right)+1 / 2 \ln \left(\mathrm{P}_{\mathrm{O} 2}\right)\right]$

- To find the losses L:

This is divided to activation losses, crossover losses, ohmic losses and concentration losses.

1. Activation losses:

This is due to slowness of reactions taking place in the cell. A proportion of the generated voltage is lost in driving the chemical reaction that transfers electrons to or from the electrode.

$$
\therefore \Delta \mathrm{V}_{\mathrm{act}}=\mathrm{A} \ln (\mathrm{i} / \mathrm{b})
$$$$
\mathrm{A}=\mathrm{A}_{\mathrm{a}}+\mathrm{A}_{\mathrm{c}} ; \text { and } \mathrm{b}=\mathrm{i}_{\mathrm{oa}}(\mathrm{Aa} / \mathrm{A})+\mathrm{i}_{\mathrm{oc}}(\mathrm{Ac} / \mathrm{A})
$$

Where; A: slope of Tafel line, it is a constant in volts and is higher for a slow reaction

$\mathrm{i}_{\mathrm{o}}$ : exchange current density, it's higher for fast reaction reducing the activation losses and improving cell performance. $\mathrm{b}$ : is a constant in amperes.

2. Fuel crossover and internal currents:

This energy loss results from the waste of fuel passing through the electrolyte (fuel crossover), as well as some electron conduction through the electrolyte (electrolyte should only transport ions), resulting in a noticeable voltage drop (added to the activation losses). Thus the final Cell activation losses become:

$$
\Delta \mathrm{V}_{\text {act }}=\mathrm{A} \ln \left[\left(\mathrm{i}+\mathrm{i}_{\mathrm{n}}\right) / \mathrm{i}_{\mathrm{o}}\right]
$$

Where; $i_{n}$ : is the internal and fuel crossover equivalent current density.

3. Ohmic losses or resistive losses:

This is due to either internal current losses caused by the leakage of some electrons passing through the membrane instead of being utilized, or due to resistive losses caused by electrons flow through the resistance of the whole electric circuit (hydrated membrane reduces ohmic losses). It is proportional to current density.

$$
\Delta \mathrm{V}_{\mathrm{ohm}}=\mathrm{ir}
$$

Where; $r$ : is the area-specific resistance.

4. Mass transport or Concentration losses:

This is due to the change in concentration of reactants at the surface of the electrodes as the fuel is used causing reduction in the partial pressure of reactants, resulting in a reduction in voltage given by:

$\Delta \mathrm{V}_{\text {trans }}=-\mathrm{RT} / \mathrm{n}^{\prime} \mathrm{F} \times \ln \left(1-\mathrm{i} / \mathrm{i}_{1}\right)$

Where; n': differs for different reactants (it is 2 for hydrogen and 4 for Oxygen).

Or $\Delta \mathrm{V}_{\text {trans }}$ can be also found by using another approach [3] that is entirely empirical and has become more favored lately, because it gives same results, provided constants $m$ and $n$ are chosen properly:

$\Delta \mathrm{V}_{\text {trans }}=-\mathrm{m} \exp (\mathrm{ni})$

The value of $\mathrm{m}$ will typically be about $3 \times 10^{-5} \mathrm{~V}$, and $\mathrm{n}$ about $8 \times 10^{-3} \mathrm{~cm}^{2} / \mathrm{mA}$.
Combining all losses, the cell voltage becomes:

$\mathrm{V}=\mathrm{E}-\Delta \mathrm{V}_{\text {ohm }}-\Delta \mathrm{V}_{\text {act }}-\Delta \mathrm{V}_{\text {trans }}$

$\therefore \mathrm{V}=\mathrm{E}-\mathrm{i} \times \mathrm{r}-\mathrm{A} \times \ln \left[\left(\mathrm{i}+\mathrm{i}_{\mathrm{n}}\right) / \mathrm{i}_{\mathrm{o}}\right]+\mathrm{m} \times \exp (\mathrm{ni})$

Equation (11) is often simplified in a practical way as the crossover current $i_{n}$ is usually very small.

$\therefore \mathrm{V}=\mathrm{E}-\mathrm{ir}-\mathrm{A} \times \ln \left(\mathrm{i} / \mathrm{i}_{\mathrm{o}}\right)+\mathrm{m} \times \exp (\mathrm{ni})$

$\mathrm{V}=\mathrm{E}-\mathrm{ir}-\left(\mathrm{A} \ln (\mathrm{i})-\mathrm{A} \ln \left(\mathrm{i}_{\mathrm{o}}\right)\right)+\mathrm{m} \times \exp (\mathrm{ni})$

Put constants together, so: $\mathrm{E}_{\mathrm{oc}}=\mathrm{E}+\mathrm{A} \ln \left(\mathrm{i}_{\mathrm{o}}\right)$

$\therefore \mathrm{V}=\mathrm{E}_{\mathrm{oc}}-\mathrm{i} \times \mathrm{r}-\mathrm{A} \times \ln (\mathrm{i})+\mathrm{m} \times \exp ($ ni)

This simplified empirical model was checked here by developing a SIMULINK [10] modular block for it. Example values of the used constants are given by table 1 . Results obtained for a Ballard $\mathrm{V}$ fuel cell [12] is given in figure 2 showing that this model is only accurate in simulating the fuel cell at operating current densities less than $1 \mathrm{~A} / \mathrm{cm}^{2}$.

TABLE I EXAMPLE CONSTANTS FOR EQUATION 14
\begin{tabular}{|l|l|}
\hline Constant & Ballard Mark V PEMFC at $70^{\circ} \mathrm{C}$ \\
\hline $\mathrm{E}_{\mathrm{oc}}(\mathrm{V})$ & 1.031 \\
$\mathrm{r}\left(\mathrm{k} \Omega \mathrm{cm}^{2}\right)$ & $2.45 \times 10^{-4}$ \\
$\mathrm{~A}(\mathrm{~V})$ & 0.03 \\
$\mathrm{~m}(\mathrm{~V})$ & $2.11 \times 10^{-5}$ \\
$\mathrm{n}\left(\mathrm{cm}^{2} / \mathrm{mA}\right)$ & $8 \times 10^{-3}$ \\
\hline
\end{tabular}

\section{Proposed Model:}

A more exact (non-simplified) model is proposed here, in which equation (5) is used to obtain the Cell Reversible Voltage $\mathrm{E}_{\mathrm{Nernst}}$ taking into account changes in temperature with respect to the standard reference temperature [3]. Then all the voltage losses are considered using the following equations:

1. Activation Losses:

The activation voltage drop, including both anode and cathode, can be calculated using [3, 5, 7, and 9]:

$\Delta \mathrm{V}_{\mathrm{act}}=-\left[\xi_{1}+\xi_{2} \times \mathrm{T}+\xi_{3} \times \mathrm{T} \times \ln \left(\mathrm{C}_{\mathrm{O} 2}\right)+\xi_{4} \times \mathrm{T} \times \ln \left(\mathrm{i}_{\mathrm{FC}}\right)\right]$

Where; $\mathrm{i}_{\mathrm{FC}}$ : is the cell operating current in (A).

$\mathrm{C}_{\mathrm{O} 2}$ : is the concentration of oxygen in the catalytic interface of the cathode $\left(\mathrm{mol} / \mathrm{cm}^{3}\right) ; \mathrm{C}_{\mathrm{O} 2}=\mathrm{P}_{\mathrm{O} 2} /\left(5.08 \times 10^{6} \times \mathrm{e}^{(-498 / \mathrm{T})}\right)$.

$\mathrm{T}$ : cell operating temperature in Kelvin $(\mathrm{K})$.

$\xi$ : parametric coefficients for each cell, whose values are defined based on theoretical equations with kinetic, thermodynamic, and electrochemical foundations.

2. Ohmic Losses:

It will be obtained using the general expression for resistance including all membrane parameters.

$\mathrm{R}_{\mathrm{M}}=\rho_{\mathrm{M}} \times \mathrm{L} / \mathrm{A}$

$\rho_{\mathrm{M}}=\left(181.6 \times\left[1+0.03 \times\left(\mathrm{i}_{\mathrm{FC}} / \mathrm{A}\right)+0.062 \times(\mathrm{T} / 303)^{2} \times\left(\mathrm{i}_{\mathrm{FC}}\right.\right.\right.$

$\left.\left./ \mathrm{A})^{2.5}\right]\right) /\left(\left[\psi-0.634-3 \times\left(\mathrm{i}_{\mathrm{FC}} / \mathrm{A}\right)\right] \times \exp [4.18 \times((\mathrm{T}-\right.$ 303)/T)] )

Where, the exponential term is the temperature correction if the cell is not operating at $30^{\circ} \mathrm{C}(303 \mathrm{~K})$.

$\Psi=14$ (ideal condition), 23 (oversaturated).

Then the ohmic voltage drop is determined by:

$\Delta \mathrm{V}_{\mathrm{ohm}}=\mathrm{i}_{\mathrm{FC}} \times\left(\mathrm{R}_{\mathrm{M}}+\mathrm{R}_{\mathrm{C}}\right)$

3. Concentration Losses:

$\Delta \mathrm{V}_{\text {con }}=-\mathrm{B} \times \ln \left(1-\mathrm{j} / \mathrm{j}_{\max }\right)$

Where; $\mathrm{j}=\mathrm{i}_{\mathrm{FC}} / \mathrm{A}$

The above proposed mathematical model equations were all implemented in MATLAB/Simulink [11, 12] software to develop a modular block (prototype) for simulating the fuel cell 


\section{VERIFICATION INVESTIGATION}

For the validation of the proposed model prototype and checking its ability to be used as a tool for simulating a fuel cell stack, a single cell model Ballard Mark V (Nafion 117) was used for the investigation. The FC parameters used for this simulation is given in table 2. Results obtained for the proposed model was then compared to those obtained using the simplified model and are both given in figure 2. Results confirm that the proposed model prototype is more accurate in simulating the fuel cell especially at higher current densities above $1 \mathrm{~A} / \mathrm{cm}^{2}$.

TABLE II PARAMETERS OF THE USED BALLARD MARK V FC

\begin{tabular}{|c|c|c|c|}
\hline Parameter & Value & Parameter & Value \\
\hline $\mathrm{T}$ & $70^{\circ} \mathrm{C}(343 \mathrm{~K})$ & $\xi_{1}$ & -0.948 \\
\hline $\mathrm{A}$ & $50.6 \mathrm{~cm}^{2}$ & $\xi_{2}$ & $\begin{array}{l}0.00286+0.0002 * \\
\ln (\mathrm{A})+\left(4.3 * 10^{-5}\right)^{*} \\
\ln \mathrm{C}_{\mathrm{H} 2}\end{array}$ \\
\hline $\mathrm{L}$ & $178 * 10^{-4} \mathrm{~cm}$ & $\xi_{3}$ & $7.6 * 10^{-5}$ \\
\hline $\mathrm{P}_{\mathrm{H} 2}$ & $1 \mathrm{~atm}$. & $\xi_{4}$ & $-1.93 * 10^{-4}$ \\
\hline $\mathrm{P}_{\mathrm{O} 2}$ & $1 \mathrm{~atm}$. & $\Psi$ & 23 \\
\hline $\mathrm{B}$ & $0.016 \mathrm{~V}$ & $\mathrm{j}_{\max }$ & $1.5 \mathrm{~A} / \mathrm{cm}^{2}$ \\
\hline $\mathrm{R}_{\mathrm{C}}$ & $0.0003 \Omega$ & $\mathrm{j}_{\mathrm{n}}$ & $0.0012 \mathrm{~A} / \mathrm{cm}^{2}$ \\
\hline
\end{tabular}

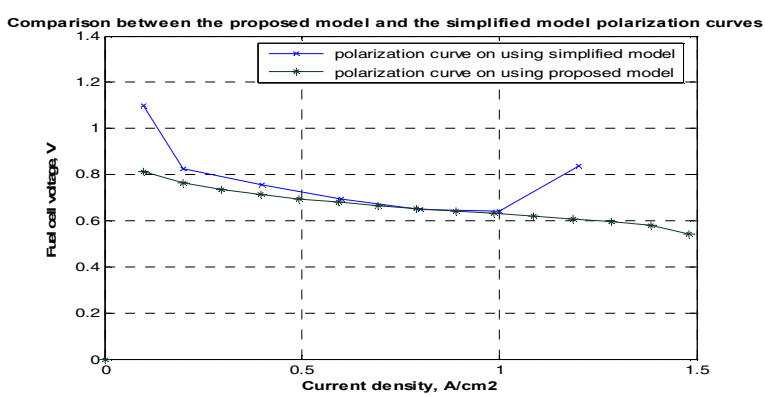

Fig. 2: The resulting Polarization Curve on using the proposed fuel cell model, compared to that obtained on using simplified model (current density up to $1500 \mathrm{~mA} / \mathrm{cm}^{2}$ or $1.5 \mathrm{~A} / \mathrm{cm}^{2}$

The FC operating temperature and the fuel/air flow are the two important dynamic properties of a fuel cell. It has to be noted that membrane temperature and gases partial pressures change with cell current, with increasing current partial pressure of hydrogen or oxygen decreases, whereas temperature increases. The proposed prototype allows the investigation of these dynamic properties, it will be demonstrated here how they will affect the fuel cell voltage. The effect of the change of cell temperature on output voltage is shown in fig. 3 , a rise of only $20^{\circ} \mathrm{C}$ results in a voltage rise.

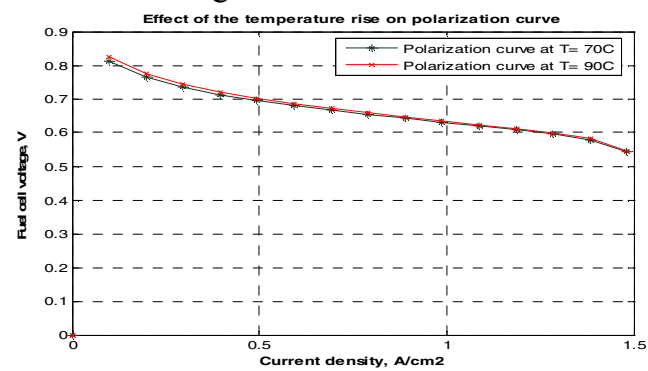

Fig. 3 Effect of temperature change on the output fuel cell voltage

The effect of the fuel/air (hydrogen \& oxygen) input pressures was also demonstrated, an increase in fuel/air input pressure from the atmospheric pressure was found to raise the exchange current density, which has an apparent effect of raising the open circuit voltage as can be seen in fig. 4 .

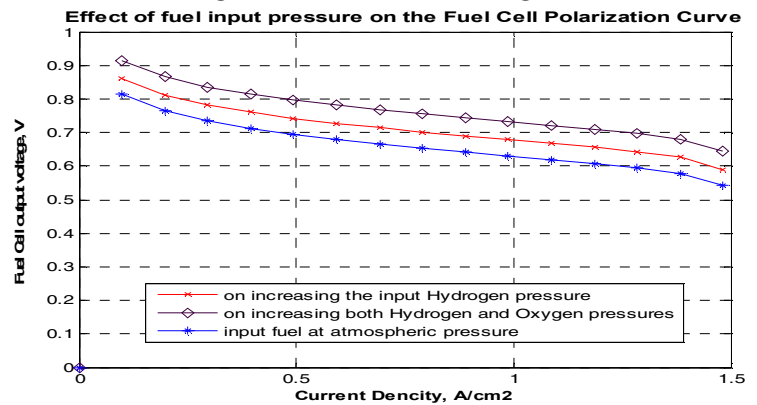

Fig. 4: Polarization Curves shows the resulting boost in fuel cell voltage when operating at a higher hydrogen and oxygen pressures

The total number of cells in a stack affects the resulting stack voltage as can be seen in Fig. 5. On using 1000 cells the stack voltage is raised to about $800 \mathrm{~V}$ at normal atmospheric pressure and low current density.

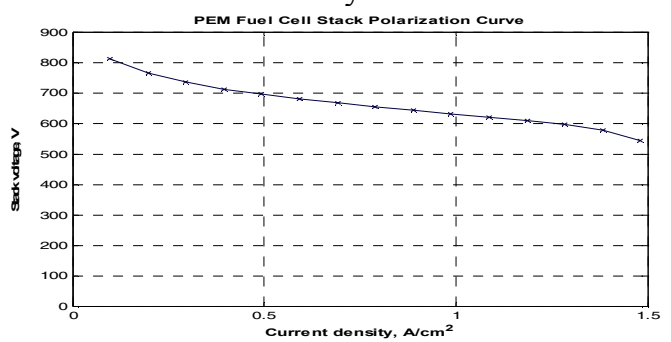

Fig. 5 The resulting polarization curve (using proposed model) for a stack PEMFC system made of 1000 cells

Correlation of the proposed model with experimental investigation for the lab Ballard NEXA ${ }^{\mathrm{TM}}$ Power module [13] given by Fig.6 is also performed. Comparisons between the proposed model predicted results and the benchmark/experimental results [13] are given in Figures $7 \& 8$ consequently confirming the validation of the proposed prototype.

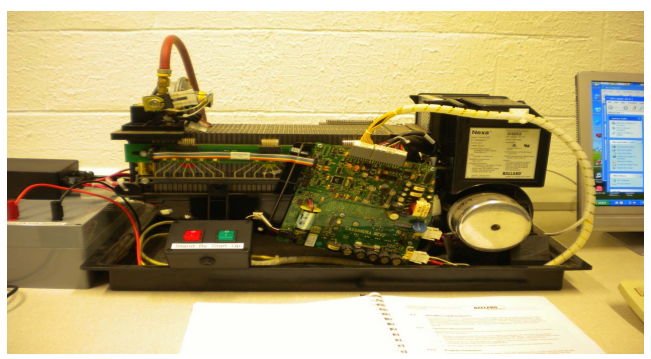

Fig. 6 Lab Ballard NEXA ${ }^{\mathrm{TM}}$ Power module

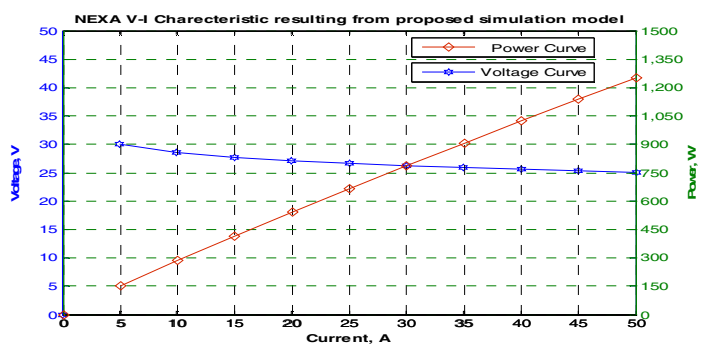

Fig. 7 Proposed Model resulting Polarization and Power Curves for the lab Ballard NEXA ${ }^{\mathrm{TM}}$ Power module 


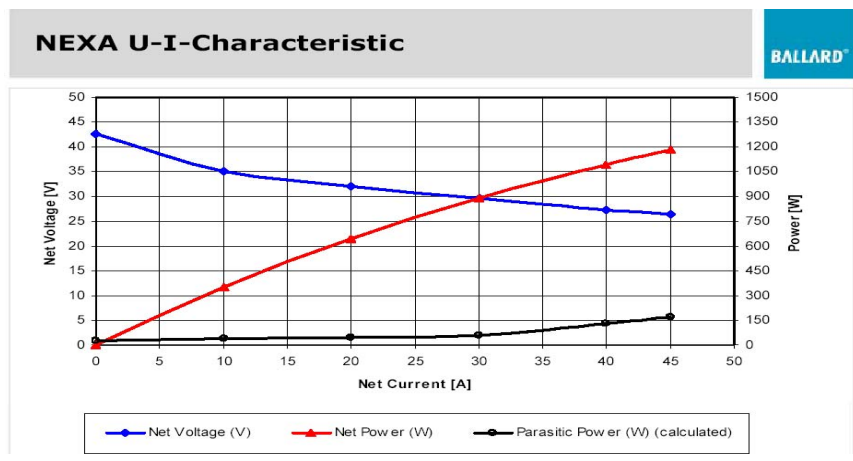

Fig. 8 Benchmark/experimental Polarization and Power Curves for the lab Ballard NEXA ${ }^{\mathrm{TM}}$ Power module

\section{STACK EFFICIENCY}

$\eta=$ electrical energy produced per mole of fuel $/-\Delta \mathrm{h}_{\mathrm{f}}$

Where: $\Delta \mathrm{h}_{\mathrm{f}},=-241.83 \mathrm{~kJ} / \mathrm{mol}$ if product is steam (HHV) and is $-285.84 \mathrm{~kJ} / \mathrm{mol}$ if product water (LHV). The maximum possible efficiency (thermodynamic efficiency) is when the electrical energy is equal to change in Gibbs free energy.

$\therefore$ Maximum efficiency possible $=\Delta \mathrm{g}_{\mathrm{f}} / \Delta \mathrm{h}_{\mathrm{f}} \times 100 \%$

The output voltage of a fuel cell $\mathbf{V}_{\mathbf{c}}$ is then related to efficiency by adapting equation (2). If all the energy from the hydrogen fuel is transformed to electrical energy, then: $\mathrm{E}=-\Delta \mathrm{h}$ $\mathrm{f} / 2 \mathrm{~F}=(1.48)$ at $\mathrm{HHV}$ and $(1.25)$ at LHV.

Therefore actual efficiency (output/input) is then:

$\eta=\left(\mathrm{V}_{\mathrm{c}} / 1.48\right) \times 100 \% \quad$ (with reference to HHV)

$\eta=\left(\mathrm{V}_{\mathrm{c}} / 1.25\right) \times 100 \% \quad$ (with reference to LHV)

However, in practice not all the fed fuel is used. Thus a fuel utilization coefficient can be defined as:

$\mu_{\mathrm{f}}=$ mass of cell's reacted fuel/mass of input fuel to cell

$\eta=\mu_{\mathrm{f}} \mathrm{V}_{\mathrm{c}} / 1.48100 \% \quad$ (with reference to HHV)

$\eta=\mu_{\mathrm{f}} \mathrm{V}_{\mathrm{c}} / 1.25100 \% \quad$ (with reference to LHV)

This equation (HHV) is implemented in both the simplified and proposed models' prototypes to obtain the efficiency curves. The resulting efficiency curves from both models for the used Ballard V PEMFC are compared in figure 9.

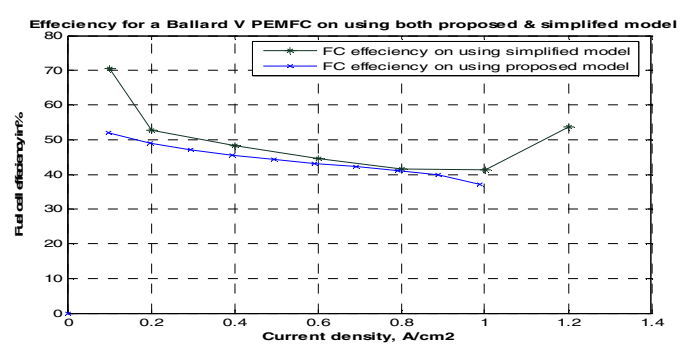

Fig. 9 Efficiency Curve using both proposed and simplified empirical models prototype (reference to $\mathrm{HHV}$ )

\section{CONCLUSION}

Two prototypes for modeling the fuel cell, by using both a simplified and the proposed mathematical models respectively, were developed tested and compared. Although the prototype produced using the simplified model gave reasonable results, the proposed model prototype was found to give better results especially at current densities greater than $1 \mathrm{~A} / \mathrm{cm}^{2}$. A further advantage of the proposed prototype is that it can be easily moderated because it is built out of different autonomous operating blocks. The proposed prototype will be used in future in many applications such as:

1. Estimate the performance of a specific fuel cell system and investigate its behaviour as an initial step toward investigating internal design modifications and/or external controller designs to improve its transient response.

2. Estimate the performance of a fuel cell system in a specific application, for example when integrated into the power grid as distributed generator.

3. Investigate the impact of the fuel cell as distributed generation (DG) on electrical power system.

\section{REFERENCES}

[1] http://www.fuelcellknowledge.org/

[2] http://www.fuelcelltoday.com/

[3] James Larminie and Andrew Dicks, Fuel cell systems explained, Second Edition, John Willey \& Sons Ltd; 2003.

[4] Boettner DD., Paganelli G., Guezennec YG., Rizzoni G., Moran MJ., "Proton exchange membrane fuel cell system model for automotive vehicle simulation and control," Journal of Energy Resources and Technology 2002; 124 (20):20-7.

[5] Denver Cheddie, Norman Munroe, "Parametric model of an intermediate temperature PEMFC," Journal of Power Sources, DTD 5, pp 1-10, 2005.

[6] Chu, D. and Jiang, R., "Performance of polymer electrolyte membrane fuel cell (PEMFC) stacks-part I. Evaluation and simulation of an air-breathing PEMFC stack," J. Power Sources, vol.83, pp. 128133, 1999.

[7] Mann R. F., Amphlett J. C., Hooper M.A. I., Jensen H. M, Peppley B. A., and Roberge P. R., "Development and application of a generalized steady-state electrochemical model for a PEM fuel cell," J. Power Sources, vol.86, 2000, pp.173-180.

[8] Lee J. H., Lalk T. R., "Modelling fuel cell stack systems," Journal of Power Sources 73 (1998), pp 229-241.

[9] Rowe, A. and Li, X., "Mathematical modelling of proton exchange membrane fuel cells," Journal of Power Sources 2001, 102, pp. 8296.

[10] Lu-Ying Chiu, Bill Diong, and Randall S. Gemmen, "An improved small-signal model of dynamic behaviour of PEM fuel cells," IEEE Transactions on Industry Applications, Vol.40, July/August 2004.

[11] William J. Palm, Introduction to Mat lab 7 for engineers, McGraw Hill.

[12] Simulink is a product of the Math-works. (http://www.mathworks.com/).

[13] "Data sheet of a $1.2 \mathrm{~kW}$ Ballard NEXA ${ }^{\mathrm{TM}}$ Power Module," Ballard Power Systems Inc., 2004 Ballard Power Systems Corp. AN2001-04.

[14] "Data sheet of one single cell model Ballard Mark V fuel cell," BCS Technologies, Englewood, CO, 2001. 